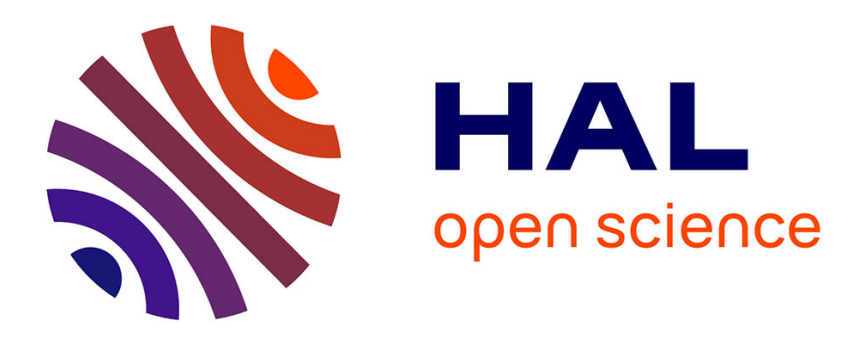

\title{
Relation between Collybia fusipes root rot and growth of pedunculate oak
}

Benoit Marçais, Olivier Caël

\section{To cite this version:}

Benoit Marçais, Olivier Caël. Relation between Collybia fusipes root rot and growth of pedunculate oak. Canadian Journal of Forest Research, 2001, 31 (5), pp.757-764. 10.1139/cjfr-31-5-757 . hal02051869

\section{HAL Id: hal-02051869 \\ https://hal.science/hal-02051869}

Submitted on 28 Feb 2019

HAL is a multi-disciplinary open access archive for the deposit and dissemination of scientific research documents, whether they are published or not. The documents may come from teaching and research institutions in France or abroad, or from public or private research centers.
L'archive ouverte pluridisciplinaire HAL, est destinée au dépôt et à la diffusion de documents scientifiques de niveau recherche, publiés ou non, émanant des établissements d'enseignement et de recherche français ou étrangers, des laboratoires publics ou privés. 
Marçais and Caël, 1

\title{
RELATION BETWEEN COLLYBIA FUSIPES ROOT ROT AND GROWTH OF PEDUNCULATE OAK
}

\author{
Benoit Marçais and Olivier Caël \\ Laboratoire de Pathologie Forestière, INRA Nancy, F-54280 Champenoux, France \\ Tel: 03833940 53; Fax: 03833940 69; Email: marcais@nancy.inra.fr
}

\section{Abstract}

Collybia fusipes is the cause of a root rot on oak, mainly pedunculate oaks and red oaks. The disease is associated with a deterioration of the crown of affected trees in some, but not all stands. We investigated the relationship between the level of root damage induced by $C$. fusipes and past growth of the infected trees at 4 sites of pedunculate oaks and a site of red oaks in north-east and central France. The severely infected oaks showed poor growth for 15 to 50 years depending on the site. At one site where $C$. fusipes was not associated with a deterioration of the affected trees crown, the basal area increment of severely root damaged oaks has nevertheless been poor for more than 30 years. Severe infection by $C$. fusipes was associated with a $30-50 \%$ reduction of basal area increment in the last ten years preceding the study at all the sites. In contrast, in all the sites, trees lightly damaged by $C$. fusipes had basal area increment similar to the undamaged trees. The data would be consistent with a disease that develops slowly on vigorous trees and affects their growth only late in the infection process.

\section{Résumé}

Collybia fusipes provoque un pourridié chez les chênes, en particulier chênes pédonculés et rouges. La maladie n'est pas associée à une dégradation du houppier des arbres infectés dans tous les peuplements atteints. Nous avons étudiés la relation entre degré d'infection du système racinaire et croissance passée des arbres infectés dans 4 peuplements de chênes pédonculés et un peuplement de chêne rouge dans le nord-est et le centre de la France. Les chênes sévèrement infectés avaient une croissance faible depuis 15 à 50 ans selon le peuplement. A Amance, où $C$. fusipes n'est pas associée à une détérioration du houppier des arbres infectés, l'accroissement en surface terrière des arbre à système racinaire fortement dégradé était faible depuis plus de 30 ans. Quelque soit le peuplement, une forte attaque par $C$. fusipes était associée à une réduction de l'accroissement en surface terrière dans les 10 ans précédent l'étude de 30 - 50\%. Par contre, dans tous les peuplements, les arbres faiblement infectés par la collybie avaitent un accroissement en surface terrière similaire à celui des arbres non infectés. Les résultats indiqueraient que le pourridié à collybie est une maladie se développant lentement et n'affectant la croissance des arbres que tard dans le processus d'infection.

\section{Introduction}

Oak decline has been reported as a chronic problem in Europe since the beginning of the $20^{\text {th }}$ century. Climatic or biotic events like drought and insect defoliations are thought to be important factors; however, the decline remains poorly understood (Hartmann et al, 1989, Landmann et al, 1993). Several root pathogens have been associated with declining oaks (Brasier et al, 1993; Bruhn et al, 2000; 
Hansen and Delatour, 1999; Jung et al, 1996; Sicoli, 1994). One of them, Collybia fusipes (Bull. Ex Fr.), was identified as the cause of a root rot during an oak decline period that occurred in central France in the early 1980's (Guillaumin et al, 1985). Though Buller (1958) and Kreisel (1961) already mentioned this fungus as a parasite of beech and oak trees, little is known about its biology. In particular, it is not known if the fungus attacks trees weakened by other factors or if it is the main cause of the decline of infected trees. Marçais et al (1998b) have shown that $C$. fusipes is common on oak trees in north-east France and is particularly associated with mature pedunculate oaks, Quercus robur L. It is also frequently present in stands of $Q$. rubra L., the red oak (Département de la santé des forêts, 1994). Artificial inoculation studies showed that $C$. fusipes is a primary pathogen, able to induce disease on vigorous young saplings and mature oak trees (Marçais and Delatour, 1996, Marçais and Caël, 2000). Red oak was highly susceptible to $C$. fusipes while sessile oak, $Q$. petraea Lieblein, was quite resistant. Pedunculate oak was intermediate in susceptibility between these two other oak species.

The presence of $C$. fusipes in oak stands is not always associated with the dieback of affected trees (Marçais et al 1998b). Dieback will be used hereafter as meaning the deterioration of the tree crown, i.e. more transparent crown and death of small branches and large limbs. In some stands, trees with severe root damage do not show strong dieback. In other places, a good relationship between root infection and crown deterioration has been found, although the crowns of affected trees may only show dieback symptoms at a late stage of the infection process (Marçais et al, 2000). Differences in dieback of severely root rotted trees might be explained by differences in the time of infection, i.e. earlier infections in stands where $C$. fusipes is associated with dieback than in stands where it is not associated with a dieback. Additionally, many trees severely damaged by $C$. fusipes do not show evidence of any other obvious predisposing cause of stress when compared to uninfected neighbors. In particular, they are not subjected to higher competition and are usually not older (Marçais et al, 2000); however, they do show a lower vigor than their uninfected neighbors as evidenced by a reduced sapwood width. It is possible that they have been stressed by insect defoliation or by recent climatic events like drought or frost.

Analysis of tree growth by dendrochronology has proved to be a powerful tool to detect past stress events that were inciting factors of oak decline (Becker, 1983; Hartmann et al, 1989; Pedersen, 1998). This tool was also used to study the impact of several root rot agents such as Inonotus tomentosus (Fr.) Teng, Phellinus weirii (Murr.) Gilberson, Armillaria ostoyae (Romagn.) Herink and Heterobasidion annosum (Fr.) Bref. on the growth of their host (Thies, 1983; Bloomberg and Reynolds, 1985; Lewis, 1997; Mallett and Volney, 1999). It has been demonstrated that trees infected by root disease show a reduced growth, that the reduction in growth depends on the severity of the infection (Froelich et al, 1977; Hřib et al, 1983; Lewis, 1997), and on the time elapsed since infection (Bendz-Hellgren and Stenlid, 1997; Bloomberg and Morrison, 1989).

The aim of this work was to study the past growth of trees infected by $C$. fusipes and to compare it to their undamaged neighbors. The specific questions we wanted to address were: i) how old is the reduction in vigor of damaged trees and can it be traced to a particular climatic event; ii) is the reduction in vigor of longer 
duration in sites where $C$. fusipes root rot is associated with a dieback than in sites where it is not; and iii) what is the magnitude of the growth reduction and is it related to the level of root damage induced by $C$. fusipes.

\section{Material and Methods}

\section{Sites examined and tree sampling}

Trees were sampled in five locations in central and north-eastern France (Table 1). The studied stands and trees were a subsample of those described in Marçais et al (2000). Amance was a healthy oak forest with very few oak trees showing dieback. In that forest, trees were selected in several coppice with standards stands (2-10 trees per stand). Coppice with standard was an old sylviculture management in which some trees, the co-called standards, were left as normal tree for timber production while the remaining trees, the coppice, were logged each 30 years for fire wood. Attention was paid to the ecological homogeneity of the sampled plot by selecting stands with similar ground vegetation. Standards consisted mainly of oaks, $Q$. robur and $Q$. petraea, and coppices of Carpinus betulus $L$. In the four other locations, trees were sampled in just one stand. In Les Aynans and Villey-St-Etienne, chronic dieback of the oak trees had been present for at least 10 years. Both stands were old coppices with standards and had only pedunculate oak in the overstory. A severe dieback of the oak trees was reported in Filain in 1995. This stand was a pedunculate oak plantation established on former agricultural land around 1900. Les Barres was a stand of northern red oak, $Q$. rubra that originated by natural regeneration in the twenties. The stand was left very dense until 1974 and has been thinned every 5 years since. A chronic dieback was reported in this stand since the early eighties.

Table. 1. Description of the study sites

\begin{tabular}{|c|c|c|c|c|c|c|}
\hline $\begin{array}{c}\text { Site } \\
\text { (Area in France) }\end{array}$ & $\begin{array}{l}\text { Oak } \\
\text { species }\end{array}$ & $\begin{array}{l}\text { Number } \\
\text { trees } \\
\text { studied }\end{array}$ & $\begin{array}{c}\text { Mean tree } \\
\text { age } \\
\text { (range) }\end{array}$ & $\begin{array}{l}\text { Mean dbh } \\
\quad(\mathrm{cm})\end{array}$ & $\begin{array}{c}\text { Soil texture } \\
\text { (Parent material) }\end{array}$ & Soil pH \\
\hline $\begin{array}{c}\text { Amance } \\
\text { (Meurthe-et-Moselle) }\end{array}$ & Q. robur & $\begin{array}{c}53 \\
(2-9 \text { per } \\
\text { stand) }\end{array}$ & $\begin{array}{c}148 \\
(90-190)\end{array}$ & 60 & $\begin{array}{l}\text { Loamy clay } \\
\text { (Calcareous clay) }\end{array}$ & $4.8-6.3$ \\
\hline $\begin{array}{c}\text { Filain } \\
\text { (Haute-Saône) }\end{array}$ & Q. robur & 42 & $\begin{array}{c}94 \\
(88-101)\end{array}$ & 43 & $\begin{array}{l}\text { Loamy clay } \\
\text { (Limestone) }\end{array}$ & 5.8 \\
\hline $\begin{array}{l}\text { Les Aynans } \\
\text { (Haute-Saône) }\end{array}$ & Q. robur & 43 & $\begin{array}{c}122 \\
(110-130)\end{array}$ & 48 & $\begin{array}{l}\text { Sandy loam } \\
\text { (Gravel) }\end{array}$ & 4.2 \\
\hline $\begin{array}{l}\text { Villey-St-Etienne } \\
\text { (Meurthe-et-Moselle) }\end{array}$ & Q. robur & 56 & $\begin{array}{c}120 \\
(75-155)\end{array}$ & 51 & $\begin{array}{l}\text { Sandy loam } \\
\text { (Gravel) }\end{array}$ & 4.3 \\
\hline $\begin{array}{c}\text { Les Barres } \\
\text { (Loiret) }\end{array}$ & Q. rubra & 71 & $\begin{array}{c}63 \\
(55-68) \\
\end{array}$ & 31 & $\begin{array}{l}\text { Sandy loam } \\
\text { (Clay) }\end{array}$ & 4.0 \\
\hline
\end{tabular}

Originally, in each stand trees were selected to have an equal number of trees with and without $C$. fusipes basidiomes at the base of the trunk. Only dominant and codominant trees were selected. C. fusipes root rot usually has a scattered distribution within the stands and trees with basidiomes were mixed together with trees without basidiomes. The tree height and the trunk diameter at breast height $(\mathrm{dbh})$ were measured. The level of infection of each tree root system was then 
assessed by observation of the collar roots after a limited excavation (Marçais et al, 2000). Lesions caused by $C$. fusipes on oak are very characteristic. The infected bark is orange in color with small white fans of mycelium scattered within the necrotic tissues. In Q. robur, a hypertrophy of the bark is usually observed. C. fusipes can consistently be isolated from such lesions (Guillaumin et al, 1985, Marçais et al, 1999). A Root Infection Index that takes values from 0, healthy, to 4, all roots dead, was then computed. This index accurately represents the extent of infection in oak root systems (Marçais et al, 1999). Trees with a rating of 0-0.3 were classified as undamaged, with very limited and superficial root lesions. Those with a rating of $0.3-$ 2 and 2-4 were classified as lightly and severely root damaged respectively. Seventeen trees at Les Barres had already been examined for $C$. fusipes root infection in 1988 using the method described above (C. Delatour, personal communication). The difference in root infection index between the two observation times, 1988 and 1995 was computed.

For the present study, only dominant pedunculate oak trees, Q. robur, were selected in Amance, Les Aynans, Filain and Villey-St-Etienne. In addition, as differences of age existed in Les Aynans between the trees undamaged or severely damaged by $C$. fusipes, we selected only trees between 110 and 130-years-old. There were no significant differences in age between trees undamaged, lightly or severely root damaged in Amance, Filain or Villey-St-Etienne (Marçais et al, 2000). In Les Barres, trees were selected by a forester in 1974 and were specifically favored by selective logging done since then; we selected for the study trees 55-68years-old. Number and characteristics of studied trees are given in Tables 1 and 2. Trees undamaged, lightly and severely damaged by $C$. fusipes did not differ in dbh, tree height and dbh / tree height ratio (Marçais et al, 2000).

\section{Data analysis}

From 1995 to 1997 depending on the stand, one core to the center of the stem was extracted at breast height from the southern side of the trunk of each tree. The annual ring widths were measured using a digitizing table coupled with a computer. The individual ring width series were then visually cross-dated using the so-called 'pointer years'. Those are defined as the calendar years when the rings in at least $70 \%$ of the trees were more than $10 \%$ narrower or wider than the previous year. Missing rings do not occur in oak (Becker et al, 1994). Basal area increment (BAI) was used instead of tree ring width because BAl is more directly related to production rate. The annual BAI curves were studied for the period where data were available for at least a third of the trees.

Curves of BAI were visually examined for growth reduction, i.e. sudden and permanent drop in the growth trend compared to undamaged trees (Pedersen, 1998, Mallett and Volney, 1999). Such permanent drop in growth are sometimes referred to as negative intervention (Pedersen, 1998). BAl of individual trees was plotted against the mean BAI of the undamaged trees of the site. To aid the visual comparison, the $\mathrm{BAI}$ of the individual tree was corrected by the mean difference between that BAI and the BAI of the undamaged trees during the first half of the tree's life. Trees that always grew slower or faster than the mean undamaged trees, but showed a similar trend throughout the study period were not recorded as showing a reduced growth. Trees were assumed to experienced growth reduction in the year in which their corrected growth dropped for the first time to less than $90 \%$ of the mean growth of 
undamaged trees and remained permanently lower throughout the end of the study period (Fig. 1). For infected trees, the year of the growth reduction was assumed to be the year where, possibly, the $C$. fusipes root rot could have started to affect tree growth.

Table 2. Mean basal area increment in each disease severity class, grouped by 10year period.

\begin{tabular}{|c|c|c|c|c|c|c|}
\hline \multirow{2}{*}{ Forest } & \multirow{2}{*}{$\begin{array}{c}\text { Root } \\
\text { infection } \\
\text { severity }\end{array}$} & \multirow{2}{*}{$\begin{array}{l}\text { No. } \\
\text { Of } \\
\text { trees }\end{array}$} & \multicolumn{3}{|c|}{ Mean annual BAI in 10-year period: } & \multirow{2}{*}{$\begin{array}{l}\text { Annual growth } \\
\text { reduction } \\
\text { Index }(\%){ }^{\dagger}\end{array}$} \\
\hline & & & 1 to 10 * & 11 to 20 & 21 to 31 & \\
\hline Amance & $\begin{array}{l}U^{\ddagger} \\
L \\
S\end{array}$ & $\begin{array}{l}22 \\
19 \\
12\end{array}$ & $\begin{array}{l}32 \mathrm{a}^{\S} \\
28 \mathrm{a}(91 \%) \\
19 \mathrm{~b}(61 \%)\end{array}$ & $\begin{array}{l}22 \mathrm{a} \\
21 \mathrm{a}(96 \%) \\
17 \mathrm{a}(78 \%)\end{array}$ & $\begin{array}{l}25 \mathrm{a} \\
21 \mathrm{ab}(82 \%) \\
17 \mathrm{~b}(68 \%)\end{array}$ & $\begin{array}{l}-10 \pm 8 \\
-36 \pm 5\end{array}$ \\
\hline Aynans & $\begin{array}{l}U \\
L\end{array}$ & $\begin{array}{r}14 \\
20 \\
9\end{array}$ & $\begin{array}{l}20 \mathrm{a} \\
14 \mathrm{a}(68 \%) \\
10 \mathrm{~b}(50 \%)\end{array}$ & $\begin{array}{l}16 \mathrm{a} \\
13 \mathrm{a}(84 \%) \\
10 \mathrm{~b}(64 \%)\end{array}$ & $\begin{array}{l}15 \mathrm{a} \\
14 \mathrm{a}(96 \%) \\
10 \mathrm{~b}(69 \%)\end{array}$ & $\begin{array}{c}-9 \pm 8 \\
-28 \pm 16\end{array}$ \\
\hline Villey-St-Etienne & $\begin{array}{l}\text { U } \\
\mathrm{L}\end{array}$ & $\begin{array}{l}18 \\
13 \\
25\end{array}$ & $\begin{array}{l}22 \mathrm{a} \\
22 \mathrm{a}(100 \%) \\
11 \mathrm{~b}(50 \%)\end{array}$ & $\begin{array}{l}21 \mathrm{a} \\
24 \mathrm{a}(113 \%) \\
13 \mathrm{~b}(62 \%)\end{array}$ & $\begin{array}{l}17 \mathrm{a} \\
19 \mathrm{a}(115 \%) \\
14 \mathrm{a}(85 \%)\end{array}$ & $\begin{aligned}+5 & \pm 14 \\
-42 & \pm 5\end{aligned}$ \\
\hline Filain & $\begin{array}{l}U \\
L\end{array}$ & $\begin{array}{l}19 \\
23\end{array}$ & $\begin{array}{l}15 \mathrm{a} \\
17 \mathrm{a}(114 \%)\end{array}$ & $\begin{array}{l}13 \mathrm{a} \\
17 \mathrm{a}(127 \%)\end{array}$ & $\begin{array}{l}15 \mathrm{a} \\
17 \mathrm{a}(117 \%)\end{array}$ & $+12 \pm 13$ \\
\hline Barres & $\begin{array}{l}U \\
\mathrm{~L}\end{array}$ & $\begin{array}{l}34 \\
22 \\
15\end{array}$ & $\begin{array}{l}21 \mathrm{a} \\
21 \mathrm{a}(100 \%) \\
14 \mathrm{~b}(67 \%)\end{array}$ & $\begin{array}{l}14 \mathrm{a} \\
14 \mathrm{a}(100 \%) \\
12 \mathrm{a}(84 \%)\end{array}$ & $\begin{array}{l}7 \mathrm{a} \\
8 \mathrm{a}(111 \%) \\
7 \mathrm{a}(100 \%)\end{array}$ & $\begin{array}{r}-4 \pm 10 \\
-28 \pm 11\end{array}$ \\
\hline
\end{tabular}

* 1 to 10 , the last ten years before the wood cores were extracted; 11 to 20,11 to 20 years before the wood cores were extracted.

$\dagger$ The annual growth reduction index is computed by assuming that the trees damaged by $C$. fusipes would have retained the same growth trend as the undamaged ones if they had not been infected i.e. they would not have shown a permanent growth reduction. Mean \pm standard error of the mean.

$\ddagger U$, trees undamaged by $C$. fusipes, with root infection index of 0.3 or less; L, lightly root damaged, with root infection index of $0.3-2$; S, severely root damaged, with root infection index of 2-4

$\S$ Within one period and one site, means with the same letter are not significantly different with the Scheffe test. The basal area increment in percent of the undamaged trees is given between the parenthesis for the lightly and severely root damaged trees.

The reduction in radial growth of trees infected by $C$. fusipes was estimated in two ways. First, the mean BAI of the oaks not, lightly or severely damaged by $C$. fusipes during each of the 3 last decades of the tree's life was compared by variance analysis using the SAS statistical package (SAS Institute Inc., Cary, North Carolina). The tree height / trunk dbh ratio was used as a covariate in the analysis and means of the groups were compared with the Scheffe test adapted for uneven group size. Second, an index reflecting growth reduction was computed after Mallett and Volney (1999). It was assumed that, if the root rotted trees had not been infected, their growth trend would have remained comparable to that of undamaged 
trees. For each root damaged tree, the mean annual BAI, I pre, was computed for the 10 year period preceding the year of the growth reduction. The mean annual BAI of the undamaged trees, $\mathrm{H}_{\text {pre }}$, was computed for the same 10-year period. Then, the mean annual BAI of each root damaged tree, $I_{\text {post }}$, was computed for the remainder of the tree's life following the year of the growth reduction. The mean annual BAI of the undamaged trees, $\mathrm{H}_{\text {post }}$ was computed for the same period. The growth reduction index was computed as $\left[1-I_{\text {post }} /\left(\mathrm{H}_{\text {post }} \times\left(I_{\text {pre }} / \mathrm{H}_{\text {pre }}\right)\right)\right] \times 100$. When the tree had shown a drop in the growth trend, the growth reduction index for the tree was computed as the ratio between mean annual BAI of the infected tree and mean annual BAI of undamaged trees during the last 25 years. Twenty-five years corresponds to the median time between the year of the growth reduction and the time of data collection. To determine whether the root damaged trees had been growing differently compared to the undamaged trees before the year of the growth reduction, the difference $\mathrm{I}_{\text {pre }}-\mathrm{H}_{\text {pre }}$ was computed for each infected tree showing a reduced growth and its mean was compared to 0 by a t-test.

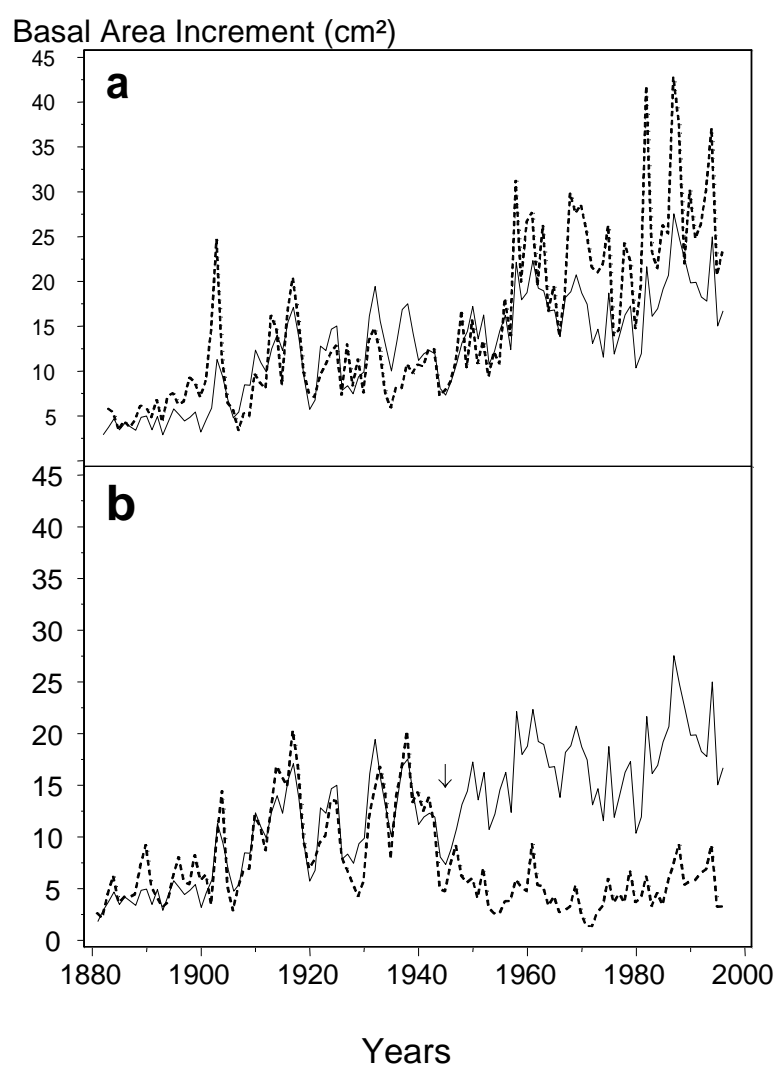

Fig. 1. Comparison of the Basal Area Increment (BAI) of two individual trees $(\cdots . . . .$.$) with the mean BAI of trees undamaged by C$. fusipes (-). The graphs represent the growth of 2 severely root damaged trees at Les Aynans, showing (a) a tree without reduced growth, and (b) a tree with a reduced growth. Arrow shows where the tree growth started to be reduced permanently. The growth curve of each individual tree is corrected by the mean difference between its BAI and the BAI of undamaged trees during the first half of the growth curve (1880-1940). 
Marçais and Caël, 7
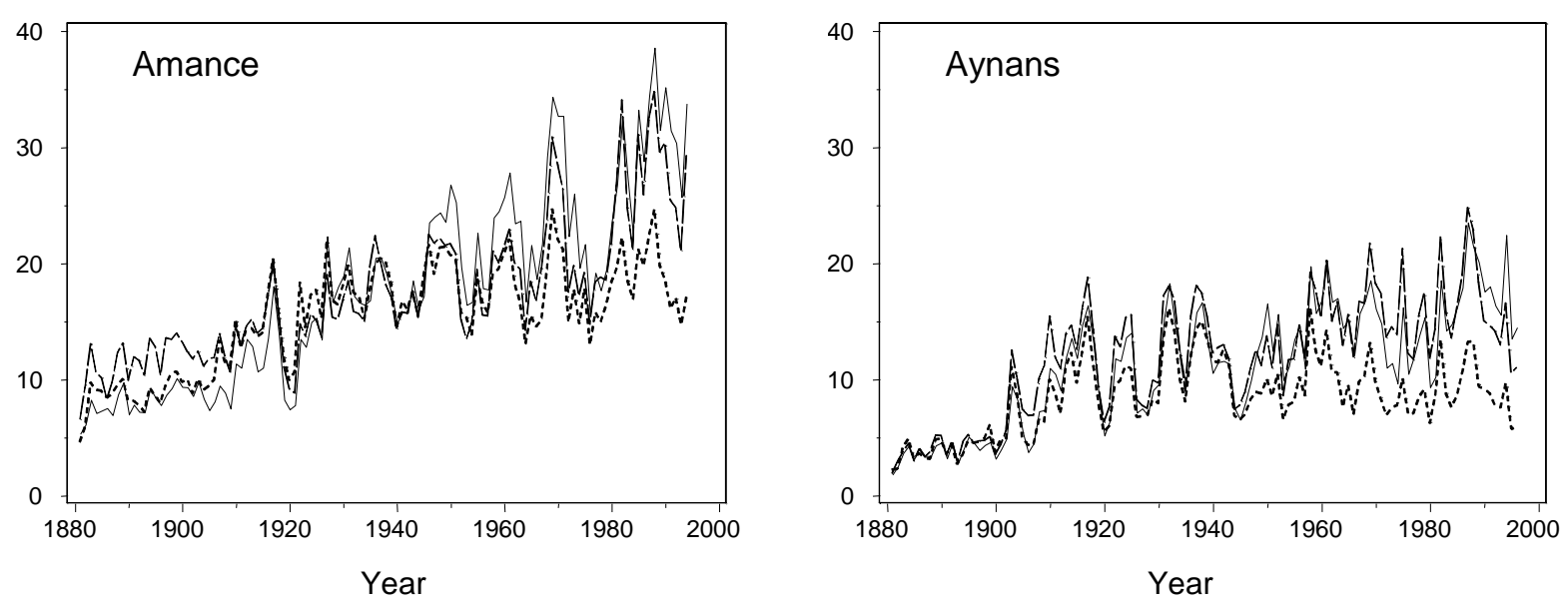

Basal Area Increment $\left(\mathrm{cm}^{2}\right)$

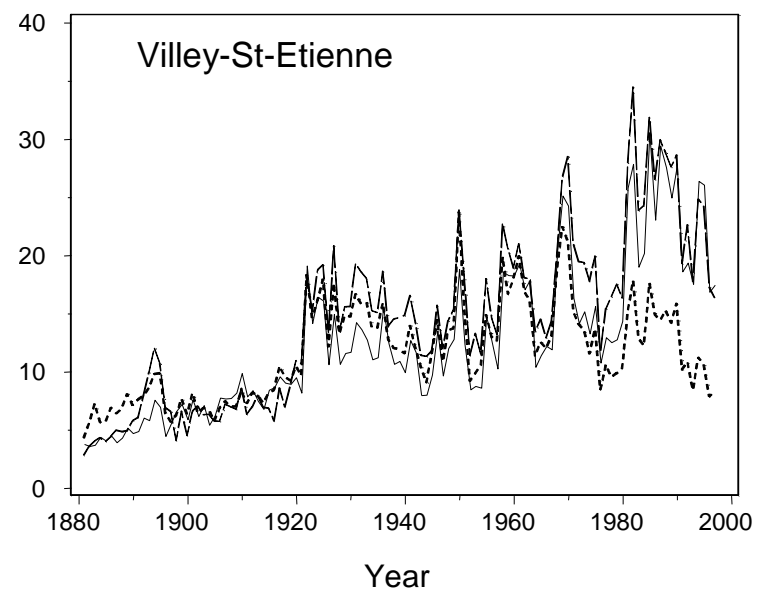

Basal Area Increment $\left(\mathrm{cm}^{2}\right)$

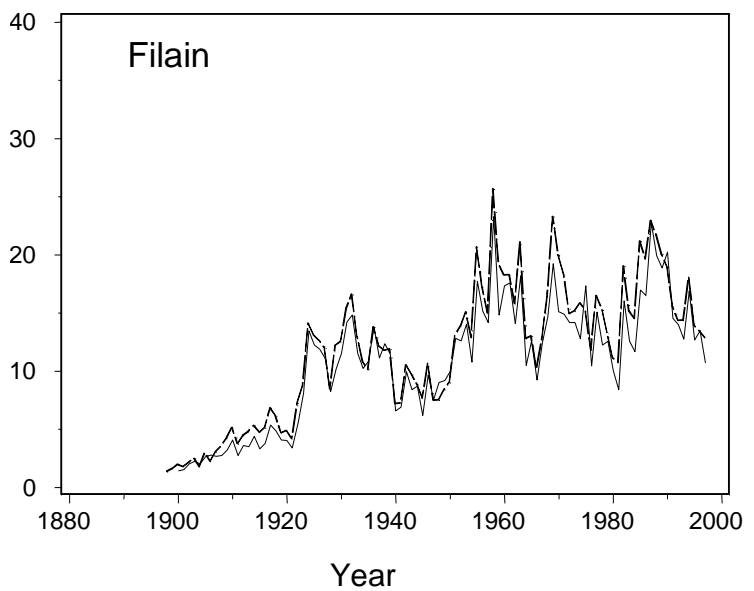

Basal Area Increment $\left(\mathrm{cm}^{2}\right)$

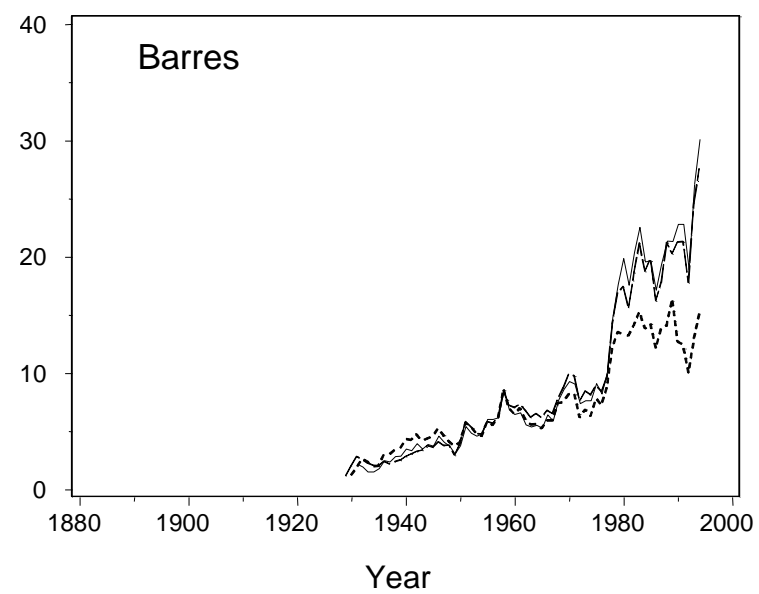

Fig. 2. Annual Basal Area Increment of oaks undamaged (-), lightly root damaged (_ - -), and severely root damaged (.......) by Collybia fusipes. Lightly damaged trees have a Root Infection Index of 0.3-2 and severely damaged trees have a Root Infection Index of more than 2. 


\section{Results}

Altogether, 96 of the 265 studied trees showed a growth reduction. The proportion of trees of a given infection class showing a reduced growth was not significantly different among the 5 studied sites $\left(\chi^{2}=6.67, \mathrm{df}=11\right.$, probability of $0.825)$ and data were pooled. The proportion of trees showing a reduced growth increased with the level of infection: $18 \%$ of the undamaged trees $(11-23 \%$ depending on the site) and respectively $30 \%(17-45 \%$ depending on the site) and $79 \%(73-84 \%$ depending on the site) of the lightly and severely root damaged trees. Still, $21 \%$ of severely infected trees had not experienced any reduction in growth and were growing at a rate comparable to the undamaged trees, with an annual BAI during the last 10 years representing $99 \%$ of the annual BAI of undamaged trees of the same site during the same period.

In the 10-year period preceding the year of the growth reduction, the root rotted trees had an annual BAI not significantly different from the undamaged trees. The mean difference $\mathrm{I}_{\text {pre }}-\mathrm{H}_{\text {pre }}$ was $4.8 \mathrm{~cm}^{2}$.year ${ }^{-1}$ in Amance $(T=2.0, \mathrm{df}=15$ probability of 0.06$), 0.4$ in Les Aynans $(T=0.5, \mathrm{df}=15$ probability of 0.63$), 2.2$ in Villey-StEtienne $(T=2.2, \mathrm{df}=23$, probability of 0.10$),-0.7$ in Filain $(\mathrm{df}=3)$ and -0.5 in Les Barres $(T=-0.6, d f=16$, probability of 0.57$)$.

Altogether, oaks lightly damaged by $C$. fusipes showed a BAI similar to the undamaged oaks (Fig. 2 and 3). In Amance, they had a lower BAl from the late 1940 s to the 1970s. In Les Aynans and Les Barres, the BAI of lightly root damaged trees was similar to the BAI of undamaged trees. In Villey-St-Etienne and Filain, lightly root damaged trees grew faster than the undamaged trees, with a BAI representing about $110-120 \%$ of the BAI of undamaged trees BAI (Fig. 3). By contrast, the severely root damaged trees at all the sites showed a strongly reduced BAI (Fig. 2). In all cases, the growth of undamaged and severely root damaged trees had been different for several decades. The difference appeared after periods of poor growth, in the late 1940s for Amance and Les Aynans and the beginning of the 1970s for Villey-St-Etienne (Fig. 2). Indeed, the median date of growth reduction was 1965 in Amance, 1947 in Les Aynans, 1968 in Villey-St-Etienne and 1987 in Filain. Many trees experienced a growth reduction in 1944-48 in Les Aynans, 1971-76 in Villey-St-Etienne and $1989-91$ in Filain $(50 \%, 38 \%$ and $50 \%$ of the trees showing a reduced growth respectively). In Amance, no particular period where many trees experienced a growth reduction could be singled out. In Les Barres, the median date of growth reduction was 1974 and in $44 \%$ of the trees showing a reduced growth it began in 1974-79, i.e. just after the stand started to be strongly thinned. The trees severely damaged by $C$. fusipes were able to increase their annual BAI in response to the thinning of 1974, though not as much as the undamaged and lightly root damaged trees (Fig. 2). After 1980, despite the repetition of the thinning every five years, their BAI declined. In all stands, the severely root damaged trees tended to grow better than the undamaged trees at the beginning of the stand's life (Fig. 3).

The oaks lightly damaged by $C$. fusipes were not significantly different from undamaged oaks for mean annual BAI on any site or for any 10 year period studied (Table 2). The growth reduction index of the lightly root damaged trees ranged from $-10 \%$ to $+12 \%$ depending on the site. The oaks severely infected by $C$. fusipes had a mean BAI significantly different from the undamaged oaks in all the sites during the 
Marçais and Caël, 9
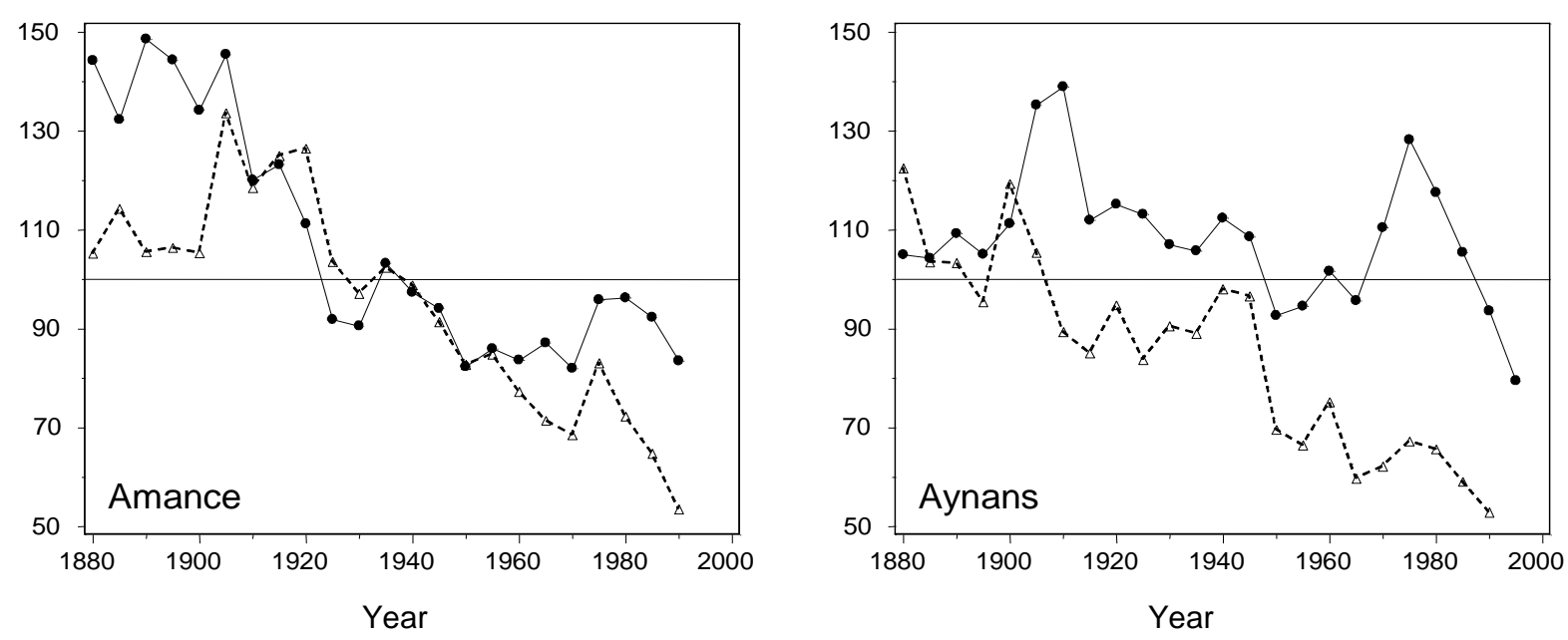

$\mathrm{BAl}$ as percent of undamaged trees

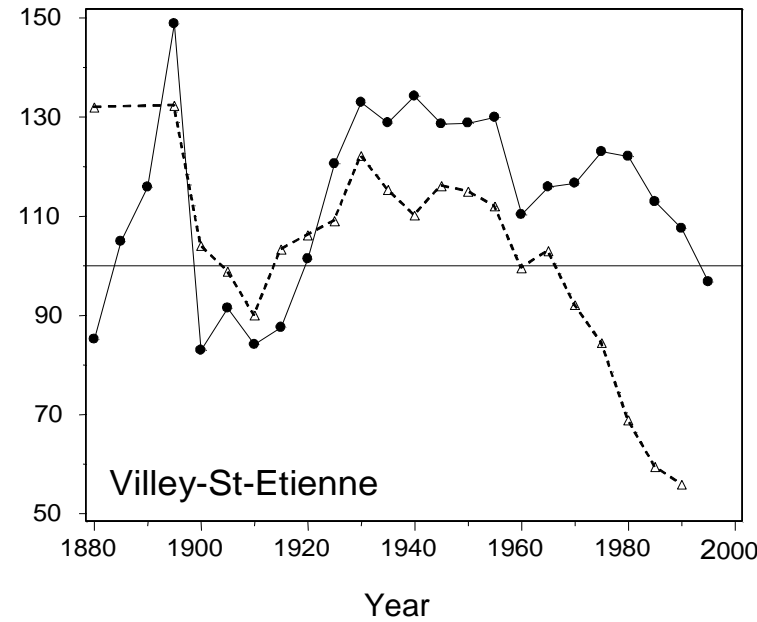

BAl as percent of undamaged trees

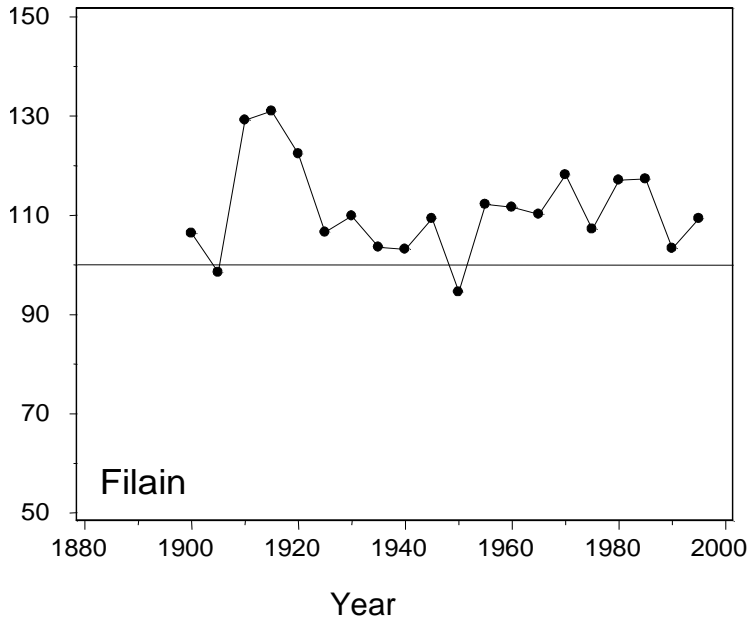

$\mathrm{BAI}$ as percent of undamaged trees

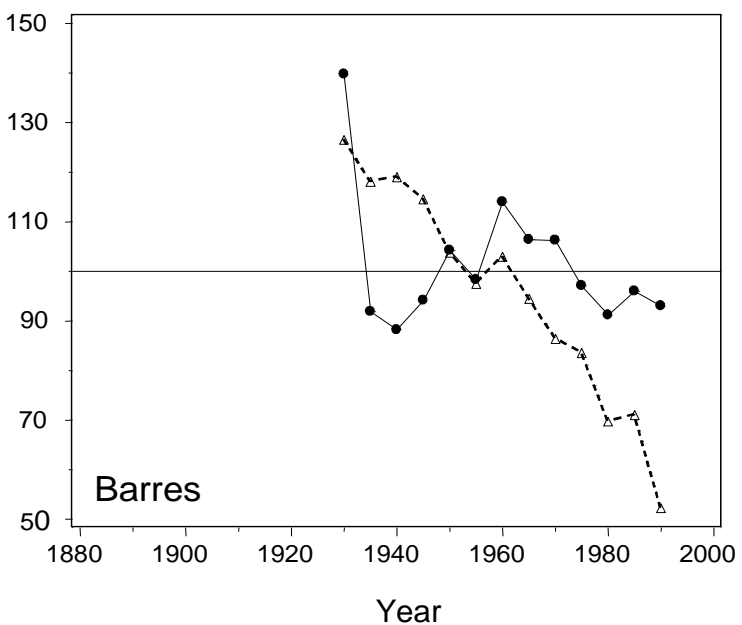

Fig. 3. Mean Basal Area Increment (BAl) per 5 year period relative to the undamaged trees of oaks lightly $(-\bullet)$ and severely $\left(-\Delta_{-}\right)$root damaged by Collybia fusipes. Lightly damaged have a Root Infection Index of 0.3-2 and severely damaged trees have a Root Infection Index of more than 2. 
last 10 year period (Table 2). The mean BAI of severely root damaged trees represented only 50 to $67 \%$ of the mean BAl of undamaged trees in this period. Severely root damaged trees also had a mean BAI significantly different from undamaged trees in the period 11 to 20 years ago at Les Aynans and Villey-StEtienne and in the period 21 to 30 years ago at Amance and Les Aynans. The difference was smaller in those two periods as the mean BAI of severely root damaged oaks represented $62-64 \%$ and $68-69 \%$ respectively of the mean BAI of undamaged oaks. For the trees severely damaged by $C$. fusipes, the growth reduction index was $-28 \%$ to $-42 \%$ depending on the site (Table 2 ).

Thirteen of the 17 red oaks of Les Barres examined for root infections in both 1988 and 1995 had lesions typical of $C$. fusipes. The evolution of the disease was very slow: mean difference between the root infection index in 1995 and 1988 was $0.3 \pm 0.1$. However, it was significantly different from 0 (Student $T$ of 2.61 , probability of 0.023 ). The 3 trees severely infected by $C$. fusipes in 1995 were already severely infected in 1988.

\section{Discussion}

Trees severely damaged by $C$. fusipes exhibited poor growth for many years. We could not determine the time at which these trees became infected by $C$. fusipes because the parasite rots the wood and it is therefore not possible to date the death of the cambium on an infected root. Therefore, we could not conclusively determine whether the root rot was the cause of the poor growth or whether trees with poor growth had higher chance of getting infected. However, we know a few trees at Les Barres that were already severely root damaged in 1988, seven years before the present study, and the evolution of the disease on infected trees in this stand appeared to be quite slow. So it is very likely that the severely root damaged trees were infected by $C$. fusipes a long time ago.

The difference between undamaged and severely root damaged trees first became apparent after periods of poor growth in 3 of the stands. Moreover, in Les Aynans, in Villey-St-Etienne and in Filain, many trees experienced a reduced growth respectively in 1944-48, 1971-76 and 1989-91. The mid forties, years after 1976 and 1989-91 have been pointed out as periods when important oak declines associated with drought occurred in NE and central France (Delatour, 1983; Becker and Levy, 1983; Landmann et al, 1993). In Filain, the soil had good water holding capacity. In Les Aynans and Villey-St-Etienne the soil was of a sandy-loam texture with a layer of gravel $50-90 \mathrm{~cm}$ below the soil surface and did not have a good water holding capacity. Thus, the trees that experienced reduced growth in 1944-48 in Les Aynans could well have been subjected to water shortage. However, in Villey-St-Etienne most of the trees experienced reduced growth before the drought year of 1976 and no drought occur in the area in the beginning of the 1970's (N. Breda, personal communication). Moreover, oak trees that go into a decline process after a stressful event like drought or insect defoliation are often trees that were less vigorous at the time of the inciting stress compared to their neighbor trees that did not decline (Pedersen, 1998). This is not the case in any of the studied stands. We could not detect any difference in BAI in the ten years period preceding the year of the growth reduction between the oaks damaged by $C$. fusipes that showed a reduced growth and the oaks undamaged. Although their growth had not yet been reduced, perhaps 
these trees were already significantly damaged by $C$. fusipes and were more likely to experience a drop in growth when stressful conditions occurred.

Indeed, growth appeared to be affected by $C$. fusipes only late in the infection process, as the lightly root damaged oaks and about one out of five of the severely root damaged oaks were growing at a rate similar to the undamaged trees. Only in Les Aynans did the lightly root damaged trees have a BAI smaller than the undamaged trees during the most recent ten year period; however, the difference was not significant. $C$. fusipes infected oaks produce many adventitious roots and might therefore compensate for killed roots by producing new roots. Obviously, the disease was able to develop on trees that were vigorous. The Filain stand was of special interest: trees were still quite young, about 90-years-old, and none were severely root damaged; this might indicate that the disease development is recent in this stand. In Filain, the oaks on which the disease developed had a growth similar to the non root rotted trees. Moreover, previous work showed that the damaged trees did not differ from the undamaged ones as far as crown appearance, competition with neighbors, age and sapwood width were concerned (Marçais et al, 2000). In Les Barres, the growth losses for the severely root damaged trees came from a poor response to thinning rather than from a decline in the BAI. So, altogether, the data would be consistent with a disease that develops slowly on trees that are not specially weakened by other factors, and causes a drastic reduction in tree growth at advanced stages of infection. This would be in agreement with the fact that vigorous mature trees and young seedlings are fully susceptible to $C$. fusipes when they are inoculated and that the induced lesions develop very slowly (Marçais and Delatour, 1996; Marçais et al, 1998b, Marçais and Caël, 2000).

The trees severely damaged by $C$. fusipes showed a larger BAl than the undamaged trees in the early stages of stand development, especially at Amance, Villey-St-Etienne and Les Barres. This could explain why, despite a reduced growth in the last decades, they had the same diameter at breast height than the undamaged trees (Marçais et al, 2000). The faster growth of infected trees in the early stage of stand development has already been described for other root rot diseases, including I. tomentosus, $P$. weirii, $A$. ostoyae and $H$. annosum and has been explained by the fact that these pathogens spread by root contact and form infection foci (Hřib et al, 1983; Bloomberg and Morrison, 1989; Bendz-Hellgren and Stenlid, 1997; Lewis, 1997, Mallett and Volney, 1999). Larger trees have a greater chance of being infected because of larger root systems and more contacts with neighbor trees. Infected trees may also be subjected to less competition than healthy trees because they are located in foci and have neighbors killed by the disease (Thies, 1983; Mallett and Volney, 1999). These explanations do not fit with $C$. fusipes biology, as this parasite does not spread by root contact, and does not form infection foci. Neighboring oaks are very infrequently infected by the same genet of $C$. fusipes (Marçais et al, 1998a). Others bias could explain the quicker growth of severely infected trees at early stages of stand development. In Les Barres, the studied trees were part of a sylviculture trial that started in 1974 and we know the initial status of the trees. The trees that were currently severely damaged by $C$. fusipes had a greater dbh in 1974 compared to undamaged trees and they were growing in better soil conditions, with traces of water logging appearing deeper in the soil (Piou et al, in preparation). These trees probably had a greater chance of being infected than those subjected to a more severe water logging because $C$. fusipes appears to be 
intolerant to water logging (Marçais, unpublished results). Also, we selected only dominant and co-dominant trees for the study. As trees severely damaged grow slower than undamaged ones, it is likely that infected trees that used to be codominant and grow slowly few decades ago were excluded from the study as they would not still be dominant or co-dominant today.

In all the stands, trees severely damaged by $C$. fusipes had significantly less growth than the undamaged trees for at least the last 10 years. The two methods used to determine the average growth reduction, the annual growth reduction index, or computing means annual BAl of damaged and undamaged oaks for 10 year periods gave similar estimates of growth reduction, i.e. 30 to $40 \%$ losses in annual BAI. This growth reduction is probably an under estimate because we selected only dominant and co-dominant trees. Indeed, the most severely affected trees suffered growth reduction since longer periods and are probably not anymore dominant or codominant today. At Amance, a forest where the disease is not associated with a deterioration of the crown of affected trees (Marçais et al 1998b; Marçais et al, 2000), growth reduction were similar than in other sites. In this forest, severely root damaged oaks have shown poor growth for at least 40 years and so there was no indication that the infection might have been recent. It is more difficult to estimate the growth losses at the stand level. Poor growth of severely root rotted trees could be compensated by a better growth of the neighbor healthy trees that benefit from reduced competition. However, Bendz-Hellgren and Stenlid (1997) could not find any relation between growth in $\mathrm{dbh}$ and height of Norway spruce and the percent of neighbors infected by $H$. annosum. Compensatory growth by the healthy trees may be minimal when the infected trees die infrequently, which is the case for $C$. fusipes infected oaks. The frequency of oaks severely damaged by $C$. fusipes was estimated to be about $10 \%$ in the most infected stands of Amance, $16 \%$ in Les Aynans, and $25 \%$ in Les Barres and Villey-St-Etienne, while no severely root damaged trees were present in Filain (Marçais et al, 2000). Thus, at the stand level, while growth losses might be significant in Les Barres and Villey-St-Etienne, they probably are small at Amance. The removal of severely root rotted trees during selective logging could minimize this growth loss. This is possible as fruiting is a reliable above-ground indicator of severe infection by $C$. fusipes (Marçais et al, 2000).

\section{Acknowledgements}

We want to thank G. Maréchal, J.E. Ménard and F. Cecconi for their technical assistance. The help of $M$. Becker and of the technicians of the laboratoire de Phytoécologie, INRA Nancy for dendrochronology data measurement and analysis was of a great help. The advice of C. Delatour, E. Hansen and J.L. Dupouey helped to improve the manuscript. We also want to thank D. Piou (ENGREF, Arboretum des Barres), the Cemagref for their help at Les Barres, the Office National des Forêts for its help at Les Aynans, Amance, Villey-St-Etienne and Filain. This work was done thanks to the support of the Office National des Forêts, France.

\section{References}

Becker, M., and Levy, G. 1983. Le dépérissement du chêne en forêt de tronçais. Les causes écologiques Ann. Sci. For. 39: 439-444

Becker, M., Nieminen, T.M., and Gérémia, F. 1994. Short-term variation and long term changes in oak productivity in northeastern France. The role of climate and atmospheric CO2. Ann. Sci. For. 51: 477-492 
Bendz-Hellgren, M., and Stenlid, J. 1997. Decreased volume growth of Picea abies in response to Heterobasidion annosum infection. Can. J. For. Res. 27: 15191524

Bloomberg, W.J., and Reynolds, G. 1985. Growth loss and mortality in Laminated root rot infection centers in second-growth Douglas-fir on Vancouver Island. Forest Sci. 31: 497-508

Bloomberg, W.J., and Morrison, D.J. 1989. Relationship of growth reduction in Douglas-fir to infection by Armillaria root disease in southeastern British Columbia. Phytopathology, 79: 482-487

Buller, A.H.R. 1958. The perennial pseudorhiza of Collybia fusipes. In: Researches on fungi, Vol. VI. pp 374-396, Hafner: New York, U.S.A.

Brasier, C.M., Robredo, F., and Ferraz, J.F.P. 1993. Evidence for Phytophhora cinnamomi involvement in Iberian oak decline. Plant Pathology, 42: 140-145.

Bruhn, J.N., Wetteroff, J.J., Mihail, J.D., Kabrick, J.M., and Pickens, J.B. 2000. Distribution of Armillaria species in upland Ozark Moutain forests with respect to site, overstory species composition and oak decline. For. Path. 30: 43-60.

Delatour, C. 1983. Les dépérissements de chênes en Europe. Revue Forestière Française. 35: 265-283.

Département de la santé des forêts 1994. La santé des forêts (France) en 1993. Ministère de l'Agriculture et de la pèche (DERF-DSF).

Froelich, R.C., Cowling, E.B., Collicott, L.V., and Dell, T.R. 1977. Fomes annosus reduces height and diameter growth of planted slash pine. Forest Sci. 23: 299306

Guillaumin, J.J., Bernard, C., Delatour, C., and Belgrand, M. 1985. Contribution à l'étude du dépérissement du chêne : pathologie racinaire en forêt de Tronçais. Ann. Sc. For. 42: 1-22.

Hartmann, G., Blank, R., and Lewark, S. 1989. Eichensterben in Norddeutschland Verbreitung, Schadbilder, mögliche Ursachen -Forst und Holz, 44: 475-487.

Hansen, E., and Delatour, C. 1999. Phytophthora species in oak forests of north-east France. Ann. Sci. For. 56: 539-547

Hřib, J., Kyncl, J., and Černý, A. 1983. A tree-ring study of Norway spruce infected with the wood-destroying fungus Armillaria mellea. Eur. J. For. Pathol. 13: 160165

Jung, T., Blaschke, H., and Neumann, P. 1996. Isolation, identification and pathogenicity of Phytophthora species from declining oak stands. Eur. J. For. Path. 26: 253-272

Kreisel, H. 1961. Die phytopathogenen grosspilze Deutschlands. VEB gustav Fischer verlag, lena, $284 \mathrm{pp}$.

Landmann, G., Becker, M., Delatour, C., Dreyer, E., and Dupouey, J.L. 1993. Oak dieback in France: historical and recent records, possible causes, current investigations. in: Rundgespräche der Kommission für Ökologie, Bd. 5 "Zustand und Gefährdung der Laubwälder“, pp 97-114. 
Lewis, K.J. 1997. Growth reduction in spruce infected by Inonotus tomentosus in central British Columbia. Can. J. For. Res. 27: 1669-1674

Mallett, K.I, and Volney, W.J.A. 1999. The effect of Armillaria root disease on lodgepole pine tree growth. Can. J. For. Res. 29: 252-259

Marçais, B., and Delatour, C. 1996. Inoculation of Oak (Quercus robur and Q. rubra) with Collybia fusipes. Plant Disease 80: 1391-1394.

Marçais, B., Martin, F., and Delatour, C. 1998a. Structure of $C$. fusipes population in two infected oak stands. Mycol. Res. 102: 361-367

Marçais, B., Caël, C., and Delatour, C. 1998b. Investigation on the distribution and impact of Collybia fusipes in oak forest. In: C. Delatour, J.J. Guillaumin, B. Lung-Escarmant and B. Marçais (ed.), Proceedings of the ninth International Conference on Root and Butt Rots of Forest Trees, Colloques de I'INRA n 89, France, pp. 215-222.

Marçais B, Caël, O., and Delatour, C. 1999. Measuring the impact of Collybia fusipes on the root system of oak trees. Ann. For. Sci. 56: 227-236

Marçais, B., Caël, O., and Delatour, C. 2000. Relationship between presence of basidiomes, above-ground symptoms and root infection by Collybia fusipes in oaks. Eur. J. For. Pathol. 30: 7-17

Marçais, B., and Caël, O., 2000. Comparison of the susceptibility of Quercus petraea, Q. robur and Q. rubra to Collybia fusipes. Eur. J. Plant. Pathol. 106: 227-232

Pedersen, B.S. 1998. The role of stress in the mortality of midwestern oaks as indicated by growth prior to death. Ecology 79: 79-93

Sicoli, G. 1994. I Funghi del genere Armillaria in Italia meridionale: identificazione, distribuzione geographica ed ecologica e patogenicotà, con particulare riferimento ai processi di infezione su querce deperienti. Tesi di Dottorato di Patologia vegetale, Università degli Studi, Bari (Italy), 44 pp.

Thies, W.G. 1983. Determination of growth reduction in douglas-fir infected by Phellinus weirii. Forest Sci. 29: 305-315 